\title{
Vaginal Adenocarcinoma
}

National Cancer Institute

\section{Source}

National Cancer Institute. Vaginal Adenocarcinoma. NCI Thesaurus. Code C7981.

An adenocarcinoma arising from the vagina. Morphologic variants include the clear cell, endometrioid, mesonephric, and mucinous adenocarcinoma. 